\title{
KEPERCAYAAN DIRI ANAK DALAM PEMBELAJARAN PENGEMBANGAN BERBAHASA PADA KELOMPOK B1 PAUD ASSALAM MUARA BANGKAHULU KOTA BENGKULU
}

\author{
Evi Martasari \\ evimartasari95@gmail.com \\ Sri Saparahayuningsih \\ srisaparahayu@yahoo.co.id \\ Delrefi D. \\ an.refi@ymail.com
}

\begin{abstract}
The problem in this research is how the child's self confidence in learning language development in group B1 PAUD AssalamMuaraBangkahulu Bengkulu City. The purpose of this study was to determine the confidence of children in learning language development in group B1 PAUD AssalamMuaraBangkahulu Bengkulu City. Type of research used in this study is descriptive quantitative research. Tecnic Data collection by using observation techniques.Data analysis using statistic with formula percentage. The result of the research shows that the Self Confidence of Children in Learning of Development of Children in Group B1 PAUD AssalamMuaraBangkahulu Bengkulu City, the result of child confidence is still enough. The details are tolerance (co-operation), optimism, decision making, and responsibility is sufficient average. Teachers should train the ability of children with learning methods of language development or teachers able to actualize the ability of children who have not developed so that the child's self-confidence is formed. To the researcher, his followers can continue this research by focusing on improvement or improvement of children's confidence, good tolerance (cooperation), optimistic, decision and responsible.
\end{abstract}

Keywords: Self-Confidence; Language Development Learning

\section{PENDAHULUAN}

Berdasarkan Undang-Undang Nomor 20 tahun 2003 tentang Sistem Pendidikan Nasional berkaitan dengan Pendidikan Anak Usia Dini tertulis pada pasal 28 ayat 1 yang berbunyi "Pendidikan Anak Usia Dini diselenggarakan bagi anak sejak lahir sampai dengan enam tahun dan bukan merupakan prasyarat untuk mengikuti pendidikan dasar". Selanjutnya pada Bab I ayat 14 ditegaskan bahwa pendidikan anak usia dini adalah suatu upaya pembinaan yang ditujukankepada anak sejak lahir sampai dengan usia enam tahunyang dilakukan melalui rangsangan pendidikan untuk membantu pertumbuhan dan perkembangan jasmani dan rohani agar anak memiliki kesiapan dalam memasuki pendidikan lebih lanjut. (Depdiknas dalam Sujiono: 2013:6). Tugas guru dalam pendidikan anak usia dini adalah membantu pertumbuhan dan perkembangan anak sehingga anak memiliki kesiapan dalam memasuki pendidikan lebih lanjut, salah satu kesiapan memasuki pendidikan lebih lanjut adalah anak memiliki kepercayaan diri.

Seperti yang dikemukakan oleh Rahayu (2013:74) kepercayaan diri merupakan modal dasar bagi anak untuk memenuhi kebutuhan hidupnya, yaitu membantu anak agar dapat diterima dilingkungannya. Kepercayaan diri tidak 
datang dengan sendirinya namun dipengaruhi oleh berbagai faktor.

Dijelaskan Angelis (dalam Rahayu, 2013:63) kepercayaan diri merupakan hal yang didengarnya anak mampu menyalurkan segala sesuatu yang diketahui dan dekerjakan. Selanjutnya Erik Erikson (dalam Rahayu, 2013:69) menyatakan bahwa anak yang percaya diri ditandai dengan toleransi (kerjasama), berani mengambil keputusan, optimis dan bertanggung jawab.

Kepercayaan diri menurut Hakim (dalam Rahayu: 2013: 70) adalah keyakinan seseorang terhadap segala aspek kelebihan yang dimilikinya dan membuat kemampuan untuk mencapai berbagai tujuan hidup.

Menurut pendapat di atas dapat disimpulkan sikap percaya diri pada anak sangatlah penting harus dipupuk sejak usia dini agar anak tidak gampang putus asa, tidak malu, tidak minder dengan orang lain untuk berkomunikasi. Dan anak-anak yang memiliki rasa percaya diri tinggi merupakan pribadi yang bisa dan mau belajar, serta berprilaku positif dalam berhubungan dengan orang dewasa sekalipun dan memiliki keyakinan atas kemampuan dirinya.

Dalam penelitian ini masalah percaya diri dijadikan fokus penelitian. Berdasarkan pengamatan yang dilakukan kelompok B1 PAUD Assalam Muara Bangkahulu Kota Bengkulu terdapat beberapa permasalahan diantaranya:

a. Masih terdapat anak yang tidak percaya diri dalam pembelajaran pengembangan bahasa yang meliputi: menyimak, berbicara, membaca, dan menulis.

b. Kepercayaan diri pada anak berkaitan dengan toleransi (bekerjasama), mengambil keputusan, optimis dan tanggung jawab.

Dalam penelitian ini, meliputi toleransi (bekerjasama), mengambil keputusan, optimis dan tanggung jawab.pengembangan

PAUD:

perkembangan

sosial-emosional,

perkembangan kognitif, perkembangan bahasa, perkembangan agama-moral, perkembangan fisik motorik, dan perkembangan seni.Dalam penelitian ini peneliti membatasi pada satu perkembangan saja yaitu perkembangan bahasa .

Permasalahan dalam penelitian ini adalah: "Bagaimanakah kepercayaan diri anak dalam pembelajaran pengembangan berbahasa pada kelompok B1 PAUD Assalam Muara Bangkahulu Kota Bengkulu".

\section{METODE}

Jenis penelitian yang digunakan dalam penelitian ini adalah penelitian deskriptif kuantitatif. Menurut Iskandar (dalam Darmadi, 2014:62), penelitian deskriptif adalah penelitian untuk memberikan uraian mengenai gejala, fenomena, atau fakta yang diteliti dengan mendeskripsikan tentang nilai variabel mandiri, tanpa bermaksud untuk menghubungkan atau membandingkan. Penelitian deskriptif kuantitatif ini cenderung menggunakan satu variabel dalam operasionalisasinya, tetapi bisa juga menggunakan dua variabel atau lebih, atau dicari sebab akibat antar variabel. Penelitian ini berusaha mendeskripsikan variabel berdasarkan indikator dan deskriptor dari variabel penelitian. Dalam analisis data, penelitian deskriptif kuantitatif dapat menggunakan statistik deskriptif yang diarahkan pada pencairan mean (rata-rata), persentase, atau modus yaitu tingkat keseringan sebuah respon atau jawaban.

Pendekatan penelitian deskriptif kuantitatif sering digunakan dalam penelitian survei. Sebuah penelitian yang memaparkan data ringkas dan sederhana untuk mengetahui deskripsi sebuah gejala, fenomena atau fakta Musfiqon (2012:61) 
Dalam penelitian ini akan melihat kondisi nyata kepercayaan diri anak dalam pembelajaran pengembangan bahasa anak yang telah ditentukan. Sehingga diperoleh gambaran tentang kepercayaan diri anak dalam pembelajaran pengembangan bahasa pada kelompok B1 PAUD AssalamMuara Bangkahulu Kota Bengkulusudah sesuai, kurang sesuai, atau tidak sesuai dengan kriteria yang diharapkan.

Dalam penelitian ini populasinya adalah anak kelompok B1 di PAUD Assalam Muara Bangkahulu Kota Bengkulu tahun ajaran 2016/2017 yang berjumlah 14 anak.

Pengambilan data dalam penelitian ini adalah observasi untuk mengumpulkan data dengancara melakukan pengamatan langsung di PAUD terhadap anak yang sedang melaksanakan pembelajaran kelompok B1 di PAUD Assalam Muara Bangkahulu Kota Bengkulu. Setelah data terkumpul akan dianalisis dengan rumus uji rata-rata

\section{HASIL DAN PEMBAHASAN Hasil}

Penelitian deskriptif kuantitatif ini dilakukan pada anak usia dini kelompok B1 di PAUD Assalam JIn. Wr. Supratman Rt. 19 Rw. 01, Muara Bangkahulu Kota Bengkulu. Subjek yang dapat diteliti dan diolah datanya berjumlah 14orang anak terdiri dari 10 anak laki-laki dan 4 orang anak perempuan.

\section{Data Penelitian}

Data penelitian diambil melalui observasi. Dalam kepercayaan diri ini meliputi: a) toleransi (kerjasama), b) optimis, c) mengambil keputusan, dan d) bertanggungjawab. Adapun data kepercayaan diri anak yang dapat dilihat dari tabel sebagai

1. Toleransi (Kerjasama) dalam menyimak dengan kategori cukup (53,37\%).
2. Toleransi (Kerjasama) dalam berbicara dengan kategori cukup $(52,14 \%)$.

3. Toleransi (Kerjasama) dalam membaca dengan kategori baik (61,42\%).

4. Toleransi (Kerjasama) dalam menulis dengan kategori baik $(66,42 \%)$.

Kepercayaan diri anak dalam pembelajaran pengembangan berbahasa di PAUD Assalam Muara Bangkahulu kota Bengkulu berada dalam kategori baik sebanyak 5 orang anak atau $35,7 \%$. Sedangkan kepercayaan diri anak dalam kategori cukup sebanyak 9 orang anak atau64,2\%. Secara individu kategori tertinggi toleransi (kerjasama) dalam pembelajaran pengembangan berbahasa adalah $A D$ dengan nilai75\% dan kategori terendah adalah $\mathrm{JH}$ dengan nilai $47,5 \%$.

Optimis Dalam Pembelajaran Pengembangan Berbahasanilai optimis dalam pembelajaran pengembangan berbahasa di PAUD Assalam Muara Bangkahulu Kota Bengkulu berada dalam katagori cukup $(59,2 \%)$.

Dengan rincian:

1. Optimis dalam menyimak dengan kategori cukup (53,57\%).

2. Optimisdalam berbicara dengan kategori cukup $(55,71 \%)$.

3. Optimisdalam membaca dengan kategori baik (61,42\%).

4. Optimisdalam menulis dengan kategori baik $(66,42 \%)$.

Kepercayaan diri anak dalam pembelajaran pengembangan berbahasa di PAUD Assalam Muara Bangkahulu kota Bengkulu berada dalam kategori baik sebanyak 5 orang anak atau35,7\%. Sedangkan kepercayaan diri anak dalam kategori cukup sebanyak 9 orang anak atau $64,2 \%$. Secara individu kategori optimis tertinggi dalam pembelajaran pengembangan berbahasa adalah $A D$ dengan nilai $75 \%$ dan kategori terendah adalah FT, RF dan ZV dengan nilai $50 \%$. 
Nilai mengambil keputusan dalam pembelajaran pengembangan berbahasa di PAUD Assalam Muara Bangkahulu Kota Bengkulu berada dalam kategori cukup $(60,2 \%)$.

Dengan rincian nilai:

1. Mengambil keputusan dalam menyimak dengan kategori cukup $(50,71 \%)$.

2. Mengambil keputusandalam berbicara dengan kategori cukup $(57,14 \%)$.

3. Mengambil keputusan dalam membaca dengan kategori baik $(67,14 \%)$.

4. Mengambil keputusandalam menulis dengan kategori baik $(66,14 \%)$.

Kepercayaan diri anak dalam pembelajaran pengembangan berbahasa di PAUD Assalam Muara Bangkahulu kota Bengkulu berada dalam kategori baik sebanyak 6 orang anak atau 42,8\%. Sedangkan kepercayaan diri anak dalam kategoricukup sebanyak 8 orang anak atau $57,1 \%$. Secara individu kategori mengambil keputusan tertinggi dalam pembelajaran pengembangan berbahasa adalah $\mathrm{AH}$ dengan nilai $75 \%$ dan kategori terendah adalah FT dengan nilai $47 \%$.

Bertanggungjawab

Dalam

Pembelajaran Pengembangan Berbahasa.

Nilai bertanggungjawab dalam pembelajaran pengembangan berbahasa di PAUD Assalam Muara Bangkahulu Kota Bengkulu berada dalam kategori cukup (60,1\%).

Dengan rincian nilai:

1. Bertanggungjawab dalam menyimak dengan kategori cukup (51,42\%).

2. Bertanggungjawab dalam berbicara dengan kategori cukup $(55,71 \%)$.

3. Bertanggungjawab dalam membaca dengan kategori baik $(67,14 \%)$.

4. Bertanggungjawab dalam menulis dengan kategori baik $(66,42 \%)$.
Kepercayaan diri anak dalam pembelajaran pengembangan berbahasa di PAUD Assalam Muara Bangkahulu kota Bengkulu berada dalam kategori baik sebanyak 7 orang anak atau $50 \%$. Sedangkan kepercayaan diri anak dengan kategori cukup sebanyak 6 orang anakatau42,8\% namun dalam kepercayaan diri dengan kategori kurang masih terdapat 1 orang anak atau $7,1 \%$. Secara individu kategori bertanggungjawab tertinggi dalam pembelajaran pengembangan berbahasa adalah $A D$ dengan nilai $72,5 \%$ dan kategori terendah adalah FT dan RF dengan nilai 47,5\%.

\section{Pembahasan}

Dalam penelitian ini ditemukan bahwa kepercayaan diri anak dalam pembelajaran pengembanganberbahasa pada kelompok B1 PAUD Assalam muara Bangkahulu kota Bengkulu berada dalam kategori cukup.

Kategori cukup artinya adalah bahwa anak-anak dalam penelitian ini belum memiliki keyakinan akan kemampuan dirinya. Sebagaimana yang dikemukakan oleh Hakim (dalam Rahayu, 2013 :70).Dari hasil ini perlu kiranya guru sebagai pendidik agar dapat melatihtoleransi (kerjasama), optimis, mengambil keputusan dan bertanggung jawab.

Dalam penelitian ini toleransi (kerjasama) dalam hal membaca dengan kategori baik atau 61,42dikarenakan anakanak setiap hari melakukan kegiatan membaca sebelum masuk ruangan kelas. Dan toleransi (kerjasama) dalam hal menulis dengan kategori baik atau 66,42 dikarenakan di PAUD Assalam lebih dominan kegiatan menulis.

Dalam penelitian ini optimis dalam hal membaca dengan kategori baik atau 61,42 dikarenakan anak-anak setiap hari melakukan kegiatan membaca sebelum masuk ruangan kelas. Dan optimis dalam hal menulis dengan kategori baik atau 66,42 
dikarenakan di PAUD Assalam lebih dominan kegiatan menulis.

Dalam penelitian ini mengambil keputusan dalam hal membaca dengan kategori baik atau 67,14 dikarenakan anakanak setiap hari melakukan kegiatan membaca sebelum masuk ruangan kelas. Dan mengambil keputusan dalam hal menulis dengan kategori baik atau 66,14 dikarenakan di PAUD Assalam lebih dominan kegiatan menulis.

Dalam penelitian ini

bertanggungjawab dalam hal membaca dengan kategori baik atau 67,14 dikarenakan anak-anak setiap hari melakukan kegiatan membaca sebelum masuk ruangan kelas. Dan bertanggung jawab dalam hal menulis dengan kategori baik atau 66,42 dikarenakan di PAUD Assalam lebih dominan kegiatan menulis.

Dalam penelitian ini toleransi (kerjasama) dalam hal menyimak dengan kategori cukup atau 53,37 dikarenakan guru kurang menguasai kelas sehingga anakanak jarang untuk memperhatikan gurunya saat berbicara. Dan toleransi (kerjasama) dalam hal berbicara dengan kategori cukup atau 52,14 dikarenakan guru di PAUD Assalam jarang melakukan kegiatan bercerita didalam kelas dan memberi kesempatan anak untuk berbicara.

Dalam penelitian ini optimis dalam hal menyimak dengan kategori cukup atau 53,57 dikarenakan guru kurang menguasai kelas sehingga anak-anak jarang untuk memperhatikan gurunya saat berbicara. Dan toleransi (kerjasama) dalam hal berbicara dengan kategori cukup atau 55,71 dikarenakan guru di PAUD Assalam jarang melakukan kegiatan bercerita didalam kelas dan memberi kesempatan anak untuk berbicara.

Dalam penelitian ini mengambil keputusan dalam hal menyimak dengan kategori cukup atau 50,57 dikarenakan guru kurang menguasai kelas sehingga anakanak jarang untuk memperhatikan gurunya saat berbicara. Dan toleransi (kerjasama) dalam hal berbicara dengan kategori cukup atau 57,14 dikarenakan guru di PAUD Assalam jarang melakukan kegiatan bercerita didalam kelas dan memberi kesempatan anak untuk berbicara.

Dalam penelitian ini bertanggungjawab dalam hal menyimak dengan kategori cukup atau 51,41 dikarenakan guru kurang menguasai kelas sehingga anak-anak jarang untuk memperhatikan gurunya saat berbicara. Dan toleransi (kerjasama) dalam hal berbicara dengan kategori cukup atau 55,71 dikarenakan guru di PAUD Assalam jarang melakukan kegiatan bercerita didalam kelas dan memberi kesempatan anak untuk berbicara.

Pelaksanaan Toleransi (Kerjasama) Dalam Pembelajaran Pengembangan berbahasa berdasarkan hasil penelitian memperoleh rata-rata 58,3 atau dalam kategori cukup. Hal ini dikarenakan dipaud Asalaam kurang menekankan kerjasama antar anak sihingga anak hanya fokus pada dirinya sendiri.

Pelaksanaan mengambil keputusan dalam pembelajaran pengembangan berbahasa berdasarkan hasil penelitian memperoleh rata-rata 60,2 atau kategori cukup. Hal ini dikarenakan guru di PAUD Asalaam jarang memberikan pilihan terhadap anak untuk melakukan kegiatan sehingga anak kurang berani dalam hal mengambil keputusan.

dalam pelaksanaan bertanggungjawab berbahasa berdasarkan hasil penelitian memperoleh rata-rata 60,1 atau kategori cukup. Hal ini dikarenakan guru di PAUD Asalaam kurang mengajarkan anak atau mendorong anak untuk bertanggungjawab dalam menyelesaikan semua kegiatan yang diberikan oleh guru.

Pelaksanaan optimis dalam pembelajaran pengembangan berbahasa berdasarkan hasil penelitian memperoleh 
rata-rata 59,2 atau dalam kategori cukup. Hal ini dikarenakan guru di PAUD Asalaam kurang meberi keyakinan dan memuji anak saat melakukakn kegiatan sehingga anak merasa kurang optimis dalam mengerjakan kegiatan yang diberikan oleh guru.

Hasil penelitian ini didukung oleh hasil penelitian Sammy (dalam Yunita, 2014:10).Toleransi adalah suatu sikap atau perilaku manusia yang tidak menyimpang dari aturan, di mana seseorang menghargai atau menghormati setiap tindakan yang orang lain lakukan. Sikap toleransi sangat perlu dikembangkan karena manusai adalah makhluk sosial dan akan menciptakan adanya kerukunan hidup.

Hasil penelitian ini didukung oleh hasil penelitian Myers (dalam Sinta 2009:7) optimis merupakan bagaimana seseorang bereaksi terhadap kegagalan sosial dalam kehidupannya, terkadang membuat hilangnya semangat untuk berusaha, akan tetapi adanya rasa optimis yang muncul dapat merubah pencapaian negatif untuk hasil yang lebih maksimal atau maupun membahagiakan individu.

Hasil penelitian ini didukung oleh hasil penelitian James (dalam Purwanto, 2009:10) pengambilan keputusan adalah proses yang digunakan untuk memilih suatu tindakan sebagai cara pemecahan masalah.

Hasil penelitian ini didukung oleh hasil penelitian Darmiatun (dalam Pulegeti, 2014:5) " tanggungjawab adalah sikap dan perilaku seseorang untuk melaksanakan tugas dan tanggung jawabnya yangsebenarnya dia lakukan terhadap diri sendiri, masyarakat, dan lingkungan.

Adapun penyebab kelemahan hasil penelitian tentang kepercayaan diri anak dalam pembelajaran pengembangan berbahasa pada kelompok B1 PAUD Assalam Muara Bangkahulu Kota Bengkulu, seperti : 1) Proses belajar mengajar yang kurang efektif dan kreatif dalam hal pembelajaran pengembangan berbahasa. 2) kurangnya guru dalam hal memuji hasil karya anak. 3) guru juga kurang memberi kebebasan pada anak untuk menentukan pilihannya. 4) dan guru juga kurang dalam hal mengajarkan anak untuk lebih bertanggungjawab menyelesaikan tugas yang diberikan. Sehingga kepercayaan diri anak dalam pembelajaran pengembangan berbahasa tidak berkembang denganoptimal.

\section{KESIMPULAN}

Berdasarkan hasil dari pembahasan penelitian dapat disimpulkan bahwa kepercayaan diri anak dalam pembelajaran pengembangan bahasa pada kelompok B1 di PAUD Assalam Muara Bangkahulu kota Bengkulu dalam kategori cukup. Baik aspek toleransi (kerjasama), optimis, mengambil keputusan dan bertanggung jawab hasilnya rata-ratanya adalah cukup.

\section{Saran}

Dalam penelitian ini terbukti bahwa anak-anak belum memiliki keyakinan akan kemampuan dirinya, oleh karena itu disarankan:

\section{a. Bagi guru}

Guru sebaiknya melatih kemampuan anak dengan metode pembelajaran pengembangan berbahasa atau guru mampu mengaktualisasikan kemampuan anak yang belum berkembang sehingga kepercayaan diri anak terbentuk.

\section{b. Bagi peneliti}

Bagi peneliti berkutnya dapat melanjutkanpenelitian ini dengan memfokuskan pada perbaikan atau peningkatan kepercayaan diri anak, baik toleransi (kerjasama), optimis, mengambil keputusan dan bertanggung jawab. 


\section{DAFTAR PUSTAKA}

Darmadi, Hamid. 2014. Metode Penelitian Pendidikan. Jakarta: Alfabeta.

Musfiqon. 2012. Metode Penelitian Pendidikan. Jakarta: Prestasi Pustaka.

Pulegeti, Nurmiati. 2014. Meningkatkan Perilaku Tanggung Jawab Melalui Permainan Makro Pada Anak.Jurnal.

Purwanto, Nurtanio Agus. 2009. Kreativitas Pemimpin Pendidikan Dalam Pengambilan Keputusan. Jurnal.

Rahayu, Aprianti Yofita. 2013. Menumbuhkan Kepercayaan Diri MelalUi Kegiatan Bercerita. Jakarta: PT Indeks.

Sinta, Angraini. 2008. Upaya Meningkatkan Kemampuan Optimis Anak Melalui Bercerita.Jurnal.

Yunita. 2014. Peningkatan Sikap Kerja Sama Melalui Kegiatan Bermain Peran Pada Anak.Jurnal. 